\title{
Ovarian Cancer pN1 TNM Finding v6
}

National Cancer Institute

\section{Source}

National Cancer Institute. Ovarian Cancer pN1 TNM Finding v6. NCI Thesaurus. Code C60899.

Ovarian cancer with metastasis to one or more regional lymph nodes. (from AJCC 6th Ed.) 